
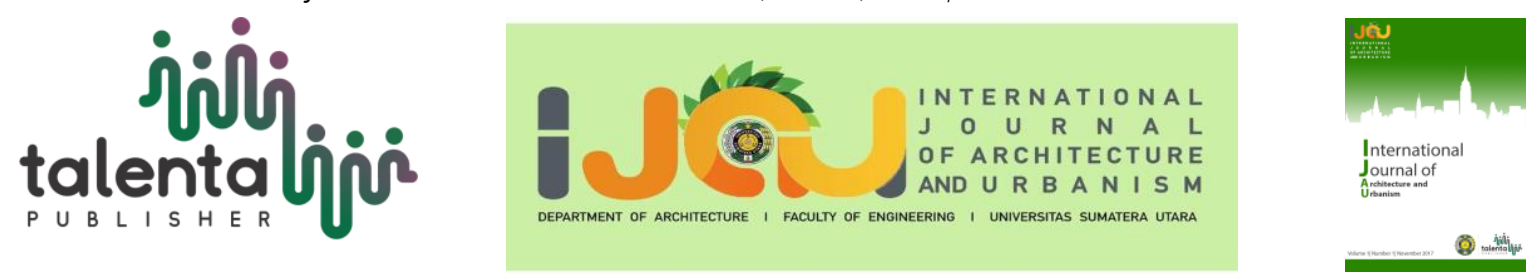

\title{
Governmental Lodging and Recreation with The Approach of Tropical Architecture
}

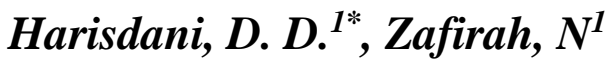 \\ 1 Department of Architecture, Faculty of Engineering, Universitas Sumatera Utara, Medan, Indonesia
}

\begin{abstract}
Lodging and recreational activity are essential activities for training, often held at office of Pusat Pengembangan, Pemberdayaan Pendidik dan Tenaga Kependidikan (PPPPTK*) Medan. Office of Pusat Pengembangan, Pemberdayaan Pendidik dan Tenaga Kependidikan (PPPPTK) Medan has had one building as a homestead, but as time progress, the demand for this homestead increase because of the increased activity in recent years. Therefore, the expansion of the homestead and recreational space design is vital to support the training activities. This homestead and outdoor recreation centre design use the methodology to solve problems using a qualitative approach and a quantitative approach by following the data and analysis of the surrounding environment as well as the established governmental building guidelines. The implementation of tropical architecture in the design makes it able to achieve efficient use of energy and be environmentally friendly. This can be seen in the mass concept, indoor concept, outdoor concept, structural concept, circulation system, and utility system. Also, this design blends with the local value of the surrounding environment by applying local wisdom.
\end{abstract}

Keyword: homestead, recreation centre, tropical architecture.

Received 6April 2021 | Revised 27 July 2021 | Accepted 15 August 2021

\section{Introduction}

Job training activities are often accompanied by lodging and recreation activities as the primary support for training that could occur for days. Pusat Pengembangan, Pemberdayaan Pendidik dan Tenaga Kependidikan (PPPPTK) office in Medan is one of the government offices that carry out these activities.

The development of Lodge and Outdoor Recreation Centre at PPPPTK Office is needed to solve the existing accommodation facilities' insufficiency in lodging and required recreational space for office activities. This development with a tropical architecture approach puts forward local

\footnotetext{
* PPPPTK : Center for Educator and Education Personnel Development and Empowerment
}

*Corresponding author at: Department of Architecture, Faculty of Engineering, Universitas Sumatera Utara, Road Perpustakaan Building J07, Medan 20155, Indonesia 
wisdom values to respond to the climate and the surrounding environment. It aims to efficiently use resources and consideration of local socio-cultural values in implementing architectural and engineering developments [1].

\section{Literature Review}

\subsection{Function and Architectural Theory}

A lodge is a collection of spaces used as a residence, office, and so on. A guesthouse is usually an accommodation building that is owned by the government and can be rented out. Outdoor Recreation Centre is a space that is intended to use as a recreational activity carried out in the open with several game simulations for individuals or groups that aim to develop cooperation between individuals and groups. Due to public use, lodges and Outdoor Recreation Centre are also tourist attractions in Medan City. It is located 15 minutes from Medan City station next to Merdeka Field, which is the zero point of Medan City and the city gate of Medan [2].

In the development of cities, especially North Sumatra Province, including Medan, Binjai, Deli Serdang, and Karo (Mebidanggro), Kualanamu International Airport functions as landmarks, and nodes have a role as transportation hubs that lead to development plans [3]. Plans must be following community needs. Differences in society's structure and socio-cultural space are urban planning problems in Indonesia [3]. This is what underlies the use of tropical architecture in the design of government accommodation and recreation buildings. Apart from that, tropical architecture has also been unconsciously applied in several traditional structures to be part of Indonesia's local wisdom. Regional conditions affect the building's shape, including architecture, construction, building materials, and philosophy, which can also be found in local wisdom [4].

Tropical architecture is an architectural concept whose purpose is to solve problems in tropical climates. Medan is a city with a tropical climate located in the lowlands with a minimum temperature between $22{ }^{\circ} \mathrm{C}$ to $24{ }^{\circ} \mathrm{C}$ and a maximum temperature between $34^{\circ} \mathrm{C}$ to $35^{\circ} \mathrm{C}$.

Indonesian architecture, which has a tropical climate, is the architecture of shade. This is due to the humid tropical conditions with two seasons and is not life-threatening, in contrast to the Eurocentric architecture that requires protection from four seasons. Roofs and columns (columns) are essential elements because they can provide the shade that humid tropical humans need but not the walls. On the other hand, Eurocentric architecture needs walls because they protect the surrounding environment [5].

\subsection{Concept}

There are four variables related to tropical buildings' physical comfort, such as room comfort, visual comfort, temperature comfort, and audio comfort [6]. A building can achieve physical 
comfort by designing the building mass and ventilation. Using energy can also help if designing mass and ventilation is not enough to reach physical comfort (Figure 1).

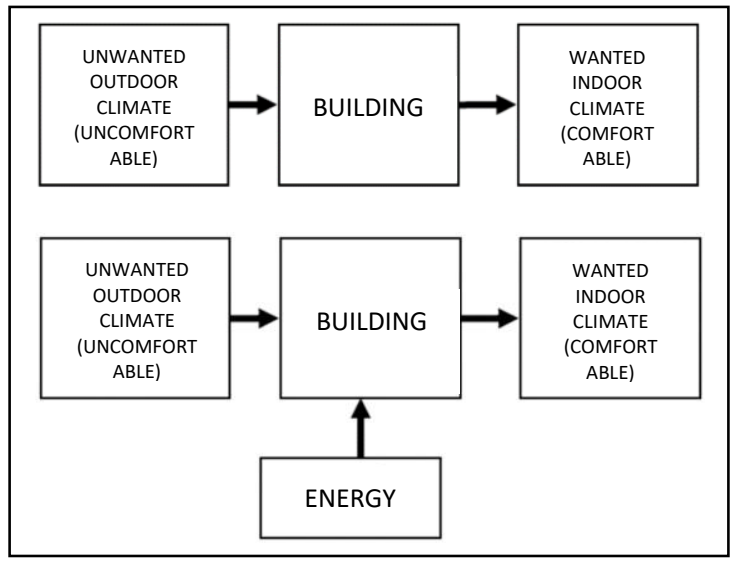

Figure 1 Activity System Concept Diagram

An example of a building that has a similar role is the Wisma Dharmala Jakarta building. Wisma Dharmala applies tropical architecture that is also influenced by the value of local wisdom. The building form makes it possible to minimize solar radiation assisted by large voids that can flow air and provide natural sunlight into space. Several sloping planes serve to block out direct sunlight and some vines that can absorb the sun's heat on the façade (Figure 2).

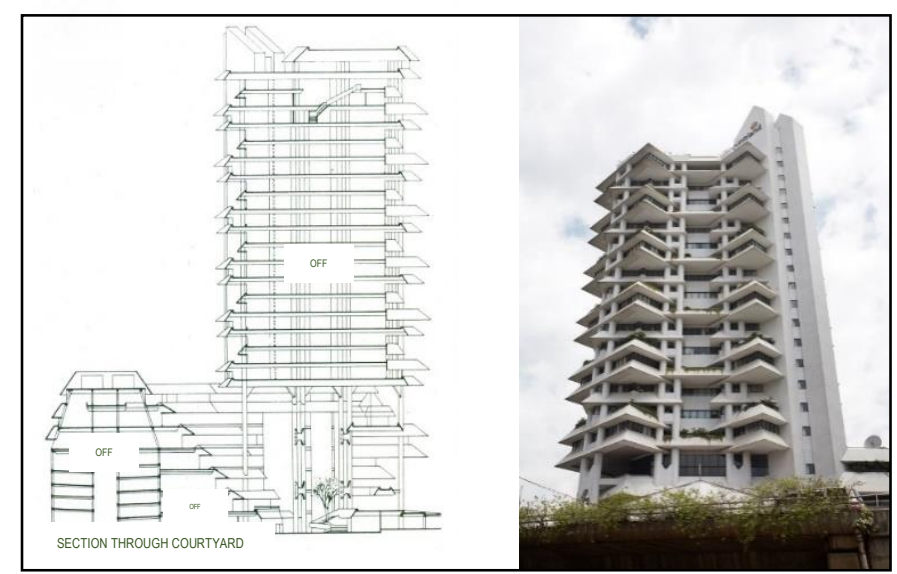

Figure 2 Intiland office

\section{Methodology}

The method used in the design of the lodge and recreation centre in the PPPPTK office is using a qualitative approach and a quantitative approach. The qualitative approach is the approach method, which is done by collecting data and information on the site, usually numbers, such as site area, building floor coefficient, building coverage ratio, green coverage ratio, and others. Meanwhile, the quantitative approach method is an approach method that is carried out by 
interpreting and analyzing the data and information been obtained to become a problem or advantage in project design.

In choosing the design location, it is necessary to pay attention to the following requirements: ownership status and land use, accessibility, surrounding environment, city utility, convenience and attractiveness of the location, and view [7] [8]. The first alternative is located at Jl. Karya, Medan Helvetia. It is owned by PPPPTK Medan, surrounded by rice fields. The second alternative is at Jl. Guru Sinumba, Medan Helvetia. It is located behind the PPPPTK office and can be connected to the office. However, the view of the surrounding is not good because of the crowded residential area. The third alternative is at Jl. Guru Sinumba I, Medan Helvetia. Located just \pm 2 $\mathrm{km}$ from the second alternative with the view of river and rice fields. But at the disadvantage of the small road access. One alternative that meets the best requirements from these alternatives is selected for the design (Table 1).

Table 1 The selection of a site that will be used as the site lodge and recreation centre.

\begin{tabular}{|c|c|c|c|c|c|c|c|c|}
\hline \multirow[t]{2}{*}{ No. } & \multirow[t]{2}{*}{ Requirements } & \multirow[t]{2}{*}{$\begin{array}{l}\text { Value } \\
(\mathbf{V})^{*}\end{array}$} & \multicolumn{2}{|c|}{$\begin{array}{l}\text { Alternative } \\
\qquad 1\end{array}$} & \multicolumn{2}{|c|}{$\begin{array}{c}\text { Alternative } \\
\quad 2\end{array}$} & \multicolumn{2}{|c|}{$\begin{array}{c}\text { Alternative } \\
\mathbf{3} \\
\end{array}$} \\
\hline & & & $\mathrm{S}^{* *}$ & V.S & $\mathrm{S}^{* *}$ & V.S & $\mathrm{S} * *$ & V.S \\
\hline 1. & $\begin{array}{l}\text { Ownership } \\
\text { status }\end{array}$ & 10 & 4 & 40 & 1 & 10 & 1 & 10 \\
\hline 2. & Accessibility & 10 & 3 & 30 & 3 & 30 & 1 & 10 \\
\hline 3. & $\begin{array}{l}\text { Surrounding } \\
\text { environment }\end{array}$ & 8 & 2 & 16 & 2 & 16 & 4 & 32 \\
\hline 4. & City utility & 8 & 2 & 16 & 2 & 16 & 1 & 8 \\
\hline 5. & $\begin{array}{l}\text { Convenience } \\
\text { and } \\
\text { attractiveness }\end{array}$ & 8 & 2 & 16 & 2 & 16 & 4 & 32 \\
\hline 6. & View & 6 & 3 & 18 & 2 & 12 & 4 & 32 \\
\hline & TOTAL & & 14 & 136 & 12 & 100 & 15 & 124 \\
\hline
\end{tabular}

\section{Description:}

* 1-10 Value (V). With 10 points being significant and 1 being insignificant ** 1-4 Score (S). With 4 points being excellent and 1 point being bad.

In terms of form, the design will be clustered according to the function of the building. This is due to the clustered organization's character that is flexible in uniting forms into size, basic shape, and orientation. The clustered organization can also be joined as a secondary addition to a larger space [9]. As a result, the clustered design that acts as a supporting function to the main PPPPTK office will be connected by a pedestrian. This will serve as a development that can be further developed without affecting the existing building's character. 


\section{$4 \quad$ Result and Analysis}

\subsection{Location}

From the assessment carried out, alternative site 1 is the most suitable compared to other alternatives (Table 1). So, alternative site 1, which is located at Jalan Karya, Kec. Medan Helvetia is the site of choice for the Wisma Development and Outdoor Recreation Centre (Figure 3).

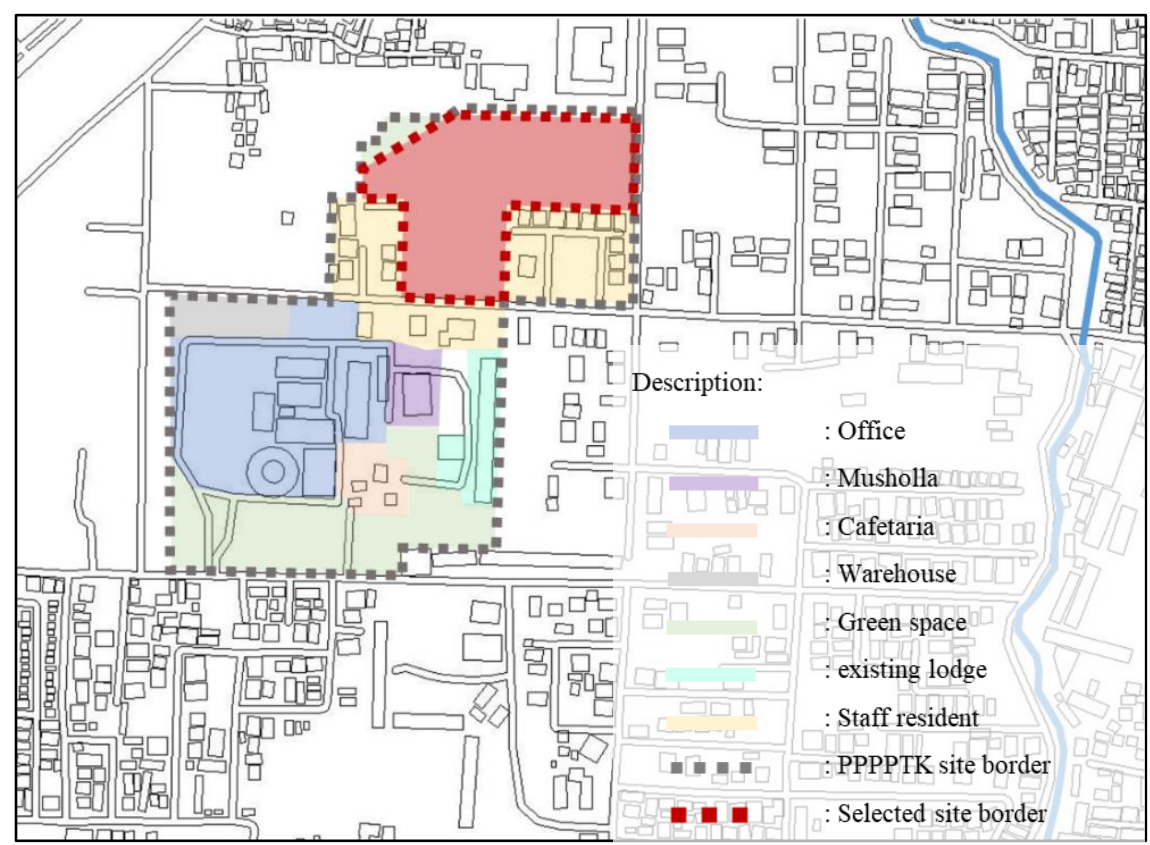

Figure 3 Selected site located behind the existing

The design is coherent with the existing PPPPTK office to achieve harmony and unity composition (Figure 4). However, other than following the rules of constructing the statebuilding rules, the current design does not implement a particular style or method [10].

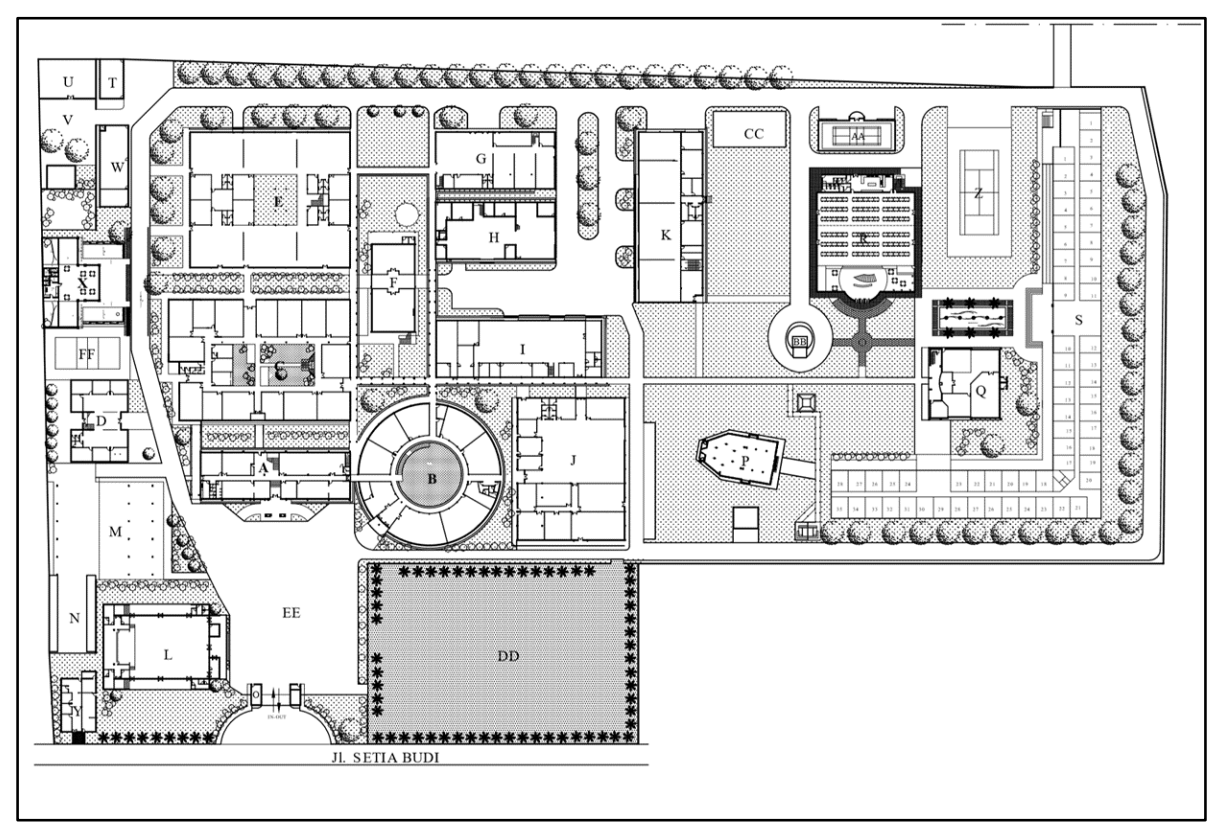

Figure 4 Masterplan of the existing PPPPTK office 


\subsection{Basic Concept}

The design of The Development of Lodge and Outdoor Recreation Centre at the PPPPTK Office Medan is a government accommodation facility. It will be designed based on government building standards with three-star hotel facilities to meet the needs of residents according to data and surveys that have been conducted [11].

The tropical architectural interpretation that will be applied to the building is to minimize the heat entering the building by protecting the walls with a roof that has a large slope, the orientation of the building is facing south, designing ventilation for natural ventilation in some spaces, using a light colour scheme, creating a pool to help cool the room, and providing green open space to provide good air influence for the site area (Figure 5).

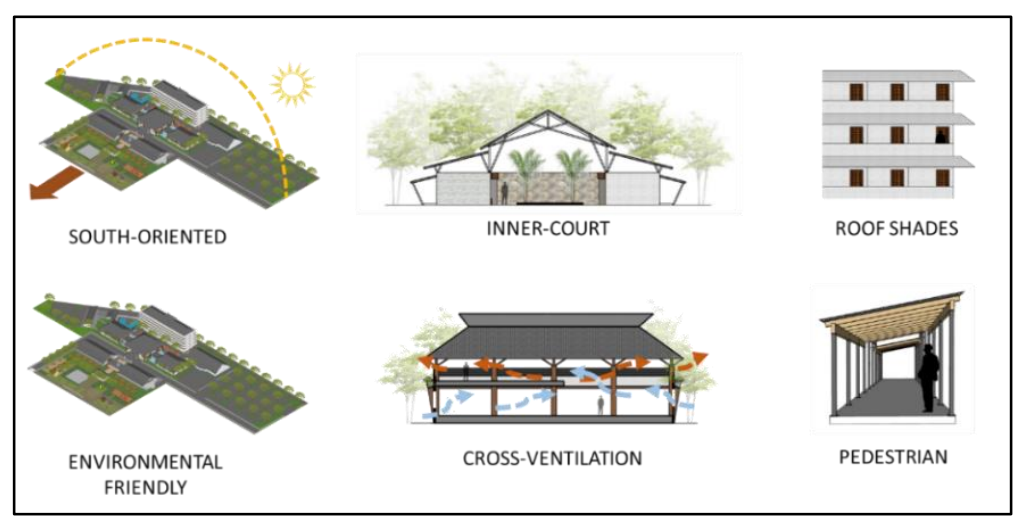

Figure 5 Implemented concepts in the design

\subsection{Spatial Planning}

Using data obtained from books and personal analysis, spatial planning, which will be applied in the design, can be seen in table 2. The measurement and its components in this spatial planning are designed with humans as the primary object [12][13][14].

Table 2 Total of Spatial Planning by Activity Group

\begin{tabular}{llc}
\hline No. & Group of Activities & Area $(\mathbf{m} 2)$ \\
\hline 1 & Public Lodging Activity & 4650,8 \\
\hline 2 & Outdoor Recreation Centre Activity & 1431 \\
\hline 3 & Maintenance & 1195,3 \\
\hline 4 & Service and Management & 1045 \\
\hline TOTAL OF SPACE FOR ACTIVITIES & 8322,1 \\
\hline TOTAL OF PARKING LOT & 2971 \\
\hline & & 11293,1
\end{tabular}




\subsection{Outdoor Circulation}

The entrance to the visitor's vehicle is at the front and enter the drop-off area in the middle of the site. Visitors can pass through an open space. In contrast, access to service is located at the back of the site (Figure 6).

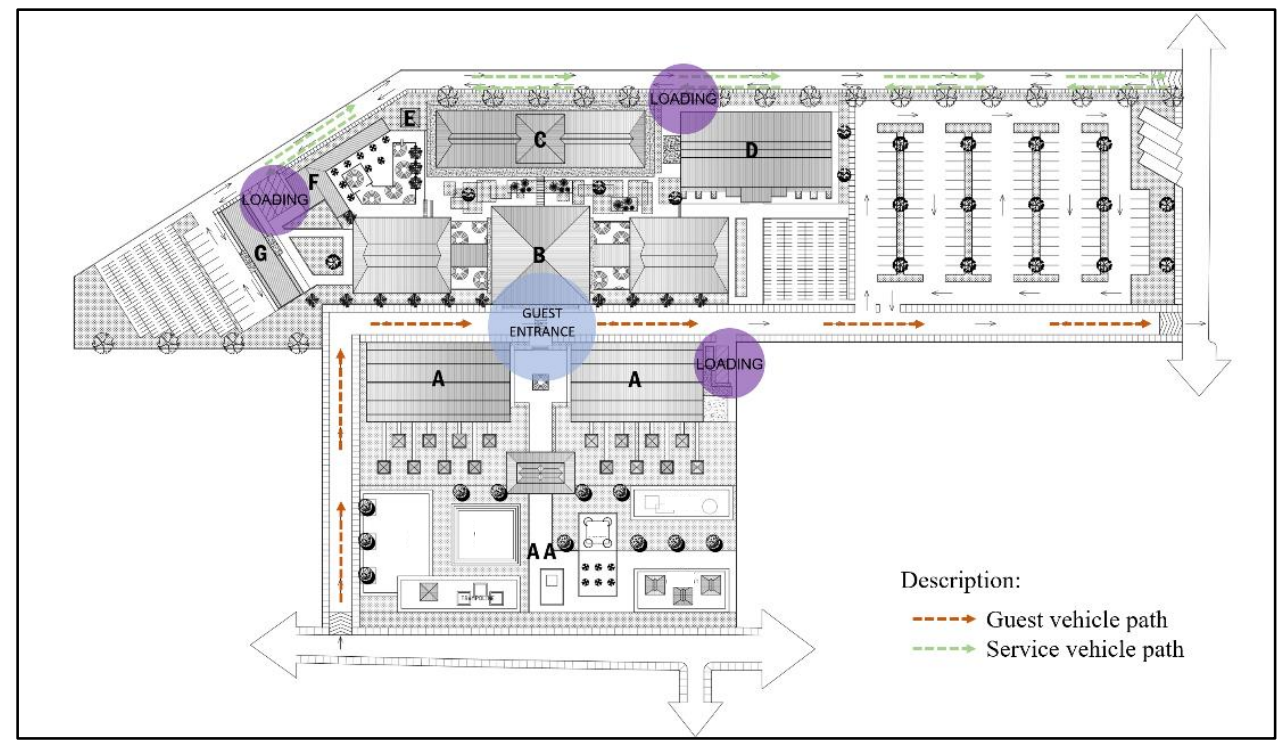

Figure 6 Vehicle Circulation and Path Diagram

\subsection{Outdoor Zoning Concept}

Outdoor zoning is divided into several types. Therefore, the design is using the multi-mass concept (Figure 7a). The area in front is the Outdoor Recreation Centre area (Figure 7b). The site's eastern area is used as a visitor's parking lot, while the western area of the site is used as a service parking lot and loading docks.

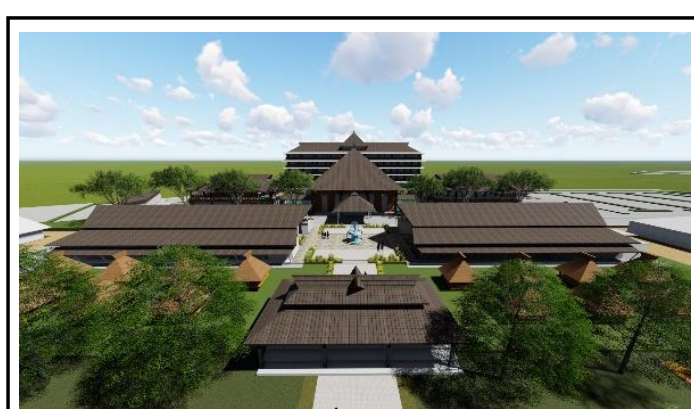

(a)

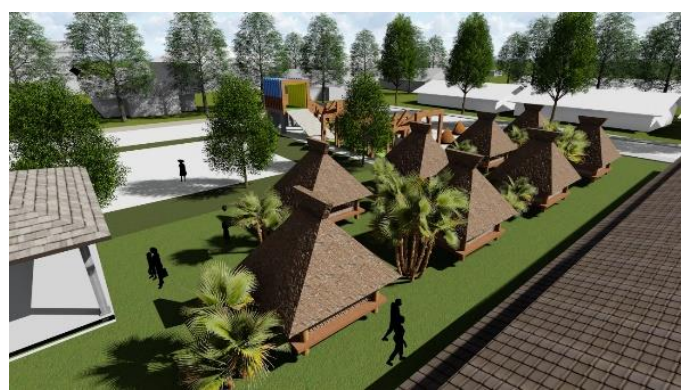

(b)

Figure 7 Site Zoning Diagram

\subsection{Indoor Zoning Concept}

There are six building masses with a different location. The outdoor Recreation Centre area is at the front of the site. This area is designed to be directly connected to the commercial building (figure $8 \mathrm{a}$ ). The concept of a linear circulation building with shops and retail along the corridor. There is also the implementation of tropical architecture indoor. For example, the use of inner- 
court in the commercial building (Figure 8a), the mezzanine for the waiting area that utilizes open ventilation and electrical fan to help reach physical comfort (Figure 8b), the restaurant that implements cross-ventilation concept (Figure 8c), and the use of high thermal mass material that can help the building stay cool inside (Figure 8d) allow the design to become energy efficient and more environmentally friendly by using natural light and ventilation.

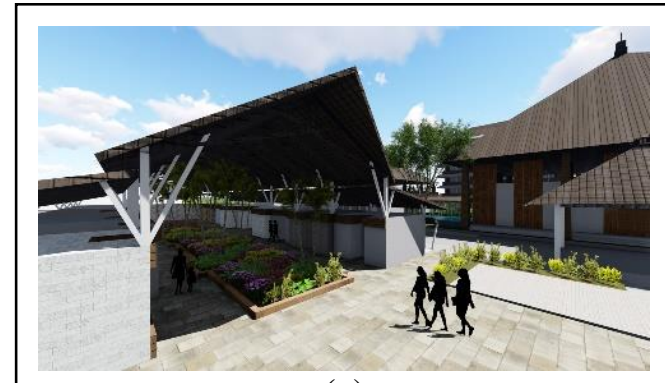

(a)

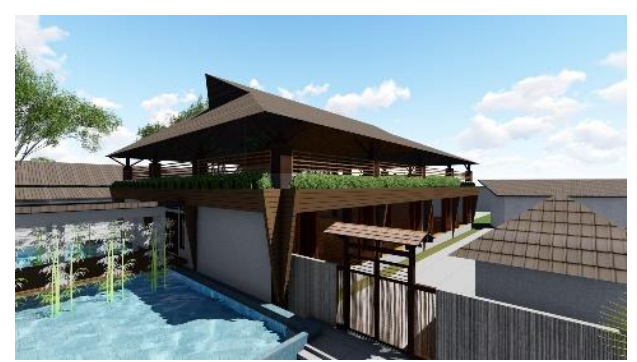

(c)

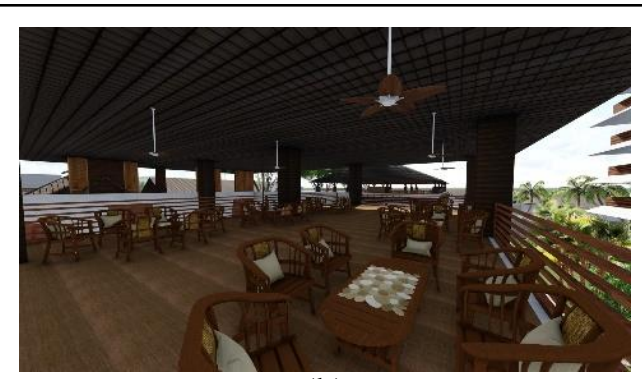

(b)

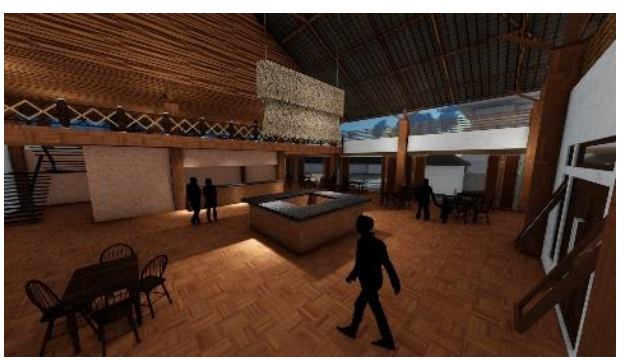

(d)

Figure 8 The implementation of tropical architecture indor

\subsection{Structure}

The upper structure used in the design is a heavy steel frame covered with a roof tile wood frame for the small gazebos wood covered with palm fibre (Figure 9).

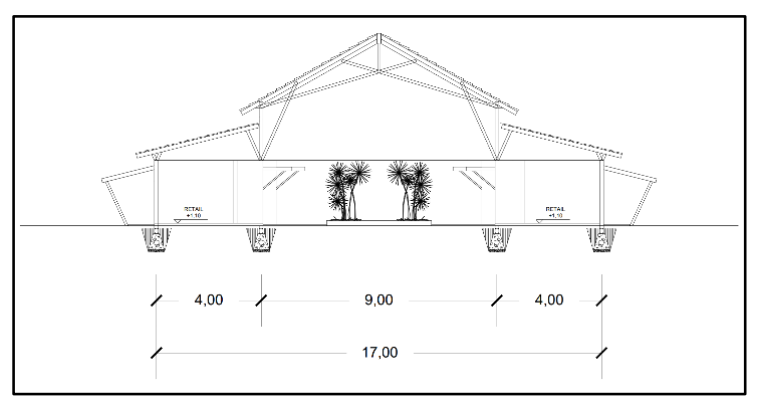

Figure 9 Section B-B in the commercial

The lower structure, which is a foundation, serves as a critical link in building loads' distribution and resolution. The foundation system must be designed to both accommodate the form and layout of the structure above and respond to the varying conditions of soil, rock, and water below [15]. Due to the existing site being a rice field, the building uses a pile foundation using a pile cap of $2,20 \mathrm{~m} \times 2,20 \mathrm{~m}$ for more than one-story building and a river stone foundation for a one-story 
building. Dilatation is used in buildings which width exceeds over 30 meters with a minimal 15centimetre distance between the columns (Figure 10).

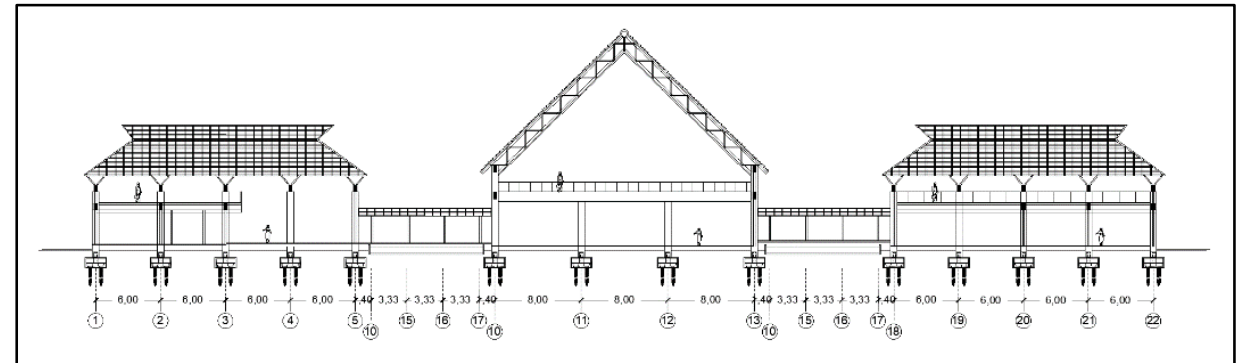

Figure 10 Section A-A in the lodge building.

\subsection{Utility}

The most affected utility by implementing tropical architecture is the type of air conditioning used in the design. The buildings that use mechanical air conditioners will be limited to private spaces and public space guest rooms and ballroom (Figure 11). Other buildings will be using natural air conditioning concepts, such as cross ventilation and air insulation, helped by mechanical fans in some areas.

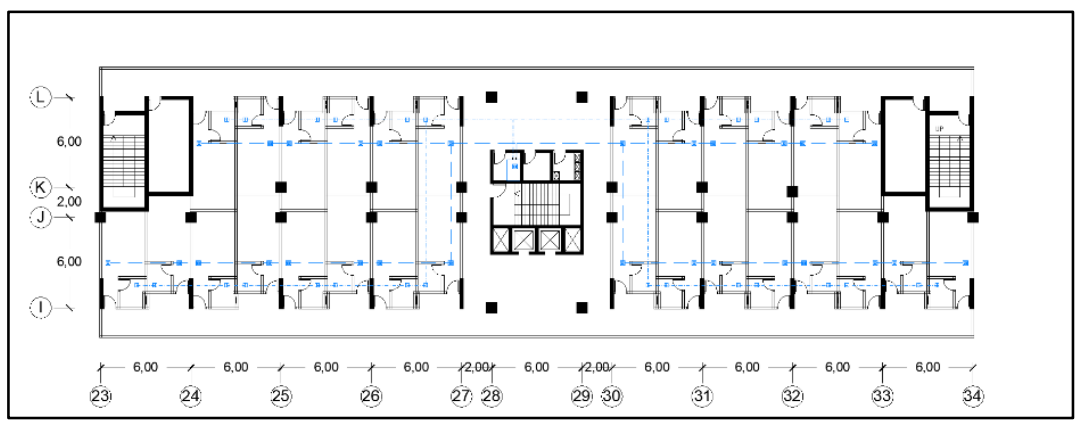

Figure 11 The usage of mechanical air conditioning in guest rooms

\section{Conclusion}

The development of the Lodge and Outdoor Recreation Centre at the PPPPTK Office is one of the several buildings whose main purpose is to support the activities related to the office. This lodge and outdoor recreation centre are designed based on established state building code standards. Namely, the building must be integrated with the surrounding location and culture. In terms of design, Tropical Architecture is chosen to be the approach because the site is in an environment with a tropical climate of 2 seasons. Therefore, the design can target the issue and context of the surrounding environment.

\section{REFERENCES}

[1] T. H. Karyono, Arsitektur Tropis: Bentuk, Teknologi, Kenyamanan, dan Penggunaan Energi, Jakarta: Erlangga, 2016. 
[2] D. Lindarto and D. D. Harisdani, "Gateway District: The Opportunities of City Gate as Growth Centre Reinforcement," International Journal of Architecture and Urbanism, vol. 03, no. 01, p. 8, 2019.

[3] A. Nasution, D. D. Harisdani and P. P. Napitupulu, "The Implementation of Aerotropolis Concept on New Town Planning and Design in Mebidangro, Sumatera Utara," IOP Conference Series: Materials Science and Engineering, vol. 180, no. 1, 2017.

[4] A. D. Diem, "Kearifan Arsitektur Lokal Dalam Beradaptasi Terhadap Kondisi Iklim Di Daerah Tropis Lembab (Studi Kasus: Pemukiman Rumah Rakit Di Sungai Musi Palembang," Journal of Architecture and Wetland Environment Studies, vol. 1, no. 1, 2012.

[5] J. Prijotomo, Prijotomo membenahi Arsitektur Nusantara, Surabaya: PT. Wastu Lanas Grafika, 2018.

[6] T. H. Karyono, "Mendefinisikan Kembali Arsitektur Tropis di Indonesia," in Desain Arsitektur, Jakarta, 2011, pp. 7-8.

[7] Pemko Medan, Medan Helvetia, Medan: https://pemkomedan.go.id/hal-medanhelvetia.html, Accessed 3 Jan 2020.

[8] S. I. Hasibuan, Implementasi Peraturan Menteri dalam Negeri Republik Indonesia Nomor 19 Tahun 2016 Tentang Pedoman Pengelolaan Barang Milik Daerah (Penghapusan Gedung BAPPEDA dan Bina Graha di Badan Pengelolaan Keuangan dan Aset Daerah Prov, 2018.

[9] F. D. Ching, Architecture: Form, space, and order, New Jersey: John Wiley \& Sons, 2014.

[10] P. BBL, "Laporan Akhir Kegiatan: Penyusunan Master Plan P4TK Medan," P4TK Medan, Medan, 2013.

[11] K. P. U. D. P. Rakyat, "Peraturan Menteri Pekerjaan Umum dan Perumahan Rakyat Nomor 22/PRT/M/2018 Tahun 2018 tentang Peraturan Menteri Pekerjaan Umum Dan Perumahan Rakyat Republik Indonesia Nomor 22/PRT/M/2018 Tentang Pembangunan Bangunan Gedung Negara," Indonesia, 2018.

[12] E. Neufert, Architects' Data, vol 1, New Jersey: Wiley and Sons, 2019.

[13] E. Neufert, Architects' Data, vol 2, New Jersey: Wiley and Sons, 2019.

[14] J. De Chiara, Time-saver standards for building types, Pennsylvania: Mc Graw-Hill International.

[15] F. D.K. Ching, Building Construction Illustrated Fourth Edition, New Jersey: Wiley and Sons, 2018. 